Original article

\title{
The effect of watermelon (Citrullus lanatus) rind ethanolic extract on the number of Leydig, Sertoli, and spermatogenic cells of rat (Rattus novergicus) exposed to heat
}

\section{Pengaruh pemberian ekstrak etanol kulit semangka (Citrullus lanatus) terhadap jumlah sel Leydig, sel Sertoli dan sel spermatogenik tikus (Rattus novergicus) yang dipapar panas}

\author{
Abrian Panggalih ${ }^{1}$, Suherni Susilowati ${ }^{2}$, Lilik Maslachah ${ }^{3 *}$, Hermin Ratnani $^{2}$, \\ Tri Wahyu Suprayogi ${ }^{2}$ \\ ${ }^{1}$ Bachelor, Doctor of Veterinary Medicine candidate, \\ ${ }^{2}$ Division of Veterinary Reproduction, ${ }^{3}$ Division of Basic Veterinary Medicine, \\ Faculty of Veterinary Medicine, Universitas Airlangga \\ *Corresponding author, e-mail: lilik-m@fkh.unair.ac.id
}

Open access under CC BY - SA license, DOI: 10.20473/ovz.v10i1.2021.7-11

Received February 9 2021, Revised February 22 2021, Accepted March 152021

Published online April 12021

\begin{abstract}
High temperatures lead to oxidative stress, which can disturb spermatogenesis process. Watermelon (Citrullus lanatus) peel contain antioxidant expected to compensate oxidative stress due to heat stress exposure. This study aimed to determine the effect of watermelon rind ethanolic extract on the number of Leydig, Sertoli, and spermatogenic cells of rats exposed to heat $\left(40^{\circ} \mathrm{C}\right)$. Twenty rats (Rattus norvegicus) were divided randomly into five groups. In the control group (T0) rats were not exposed to heat nor given the watermelon rind extract. T1, T2, T3, and T4 groups were exposed to heat for an hour daily and orally given placebo (1\% Na CMC), 100, 200, and $400 \mathrm{mg} / \mathrm{kg} \mathrm{BW}$ of watermelon rind extract (in $1 \% \mathrm{Na}$ CMC). Rats were treated for 52 days, and sacrificed for the testicle collection. Hematoxylin-eosin stained histological slides were prepared for the examination of Leydig, Sertoli and spermatogenic cells. The results showed no significant difference $(p>0.05)$ in the average number of Leydig cells in rats among groups. The number of Sertoli cells and spermatogenic cells of rats exposed to heat (T1) was lower than those of the normal rats (T0 group). The dose of watermelon rind ethanolic extract at $200 \mathrm{mg} / \mathrm{kg} \mathrm{BW} \mathrm{(T3} \mathrm{group)} \mathrm{and} 400 \mathrm{mg} / \mathrm{kg} \mathrm{BW}$ (T4) increased ( $p<0.05)$ the number of Sertoli and spermatogenic cells. It could be concluded that a dose of $400 \mathrm{mg} / \mathrm{kg} \mathrm{BW}$ of watermelon rind ethanolic extract maintained the number of Leydig cells, Sertoli cells, and spermatogenic cells of rats exposed to heat.
\end{abstract}

Keywords: heat, watermelon rind ethanolic extract, Leydig cell, Sertoli cell, spermatogenic cell

\section{INTRODUCTION}

Spermatogenesis is a temperature-sensitive process that needs a temperature of $2-7^{\circ} \mathrm{C}$ below core body temperature to ensure the production of normal spermatozoa. Heat stress exposure to mammals' testicles impairs spermatogenesis and leads to low spermatozoa quality in the ejaculate (Aldahhan and Stanton, 2021). The spermatogenesis process occurs in the lumen of the seminiferous tubules. Spermatogenesis involves Sertoli cells (nourishing spermatogonia cells) to develop into primary spermatocytes and Leydig cells (produce testosterone) for the 
maturation of spermatozoa cells. The process of spermatozoa formation is influenced by several factors such as hormones, nutrition, and temperature. Failure to maintain testicular temperature will cause spermatozoa damage. Exposure to hot temperatures can lead to heat stress, a condition where there is an increase in the environment's unfavorable temperatures. Continuous heat stress conditions will lead to oxidative stress. There is an imbalance in the number of antioxidants and free radicals in the body (Werdhasari, 2014).

Free radicals can be neutralized physiologically by an endogenous antioxidant; unfortunately, environmental factors, such as heat stress, can decrease this capacity. Therefore, antioxidant treatment is expected to fight free radical-induced oxidative stress and improve spermatogenesis (Reynertson, 2007; Asadi et al., 2017). One of the exogenous antioxidants is Lycopene. Lycopene is one of the best antioxidants found in natural foods. Lycopene's mechanism in preventing free radicals is by donating electrons to free radical compounds to become stable (Durairajanayagam et al., 2014). Watermelon peel was reported to contain $48.8 \%$ of lycopene. Lycopene is commonly found in the white part of watermelon rind (Erhirhie and Ekene, 2013; Rahman, 2013). Many people avoid the white part of watermelon rind because it has an unpleasant taste (Filla, 2013). In this study, the watermelon rind extract was used to see its effect on the number of Leydig cells, Sertoli cells, and spermatogenic cells of rats exposed to hot temperatures.

\section{MATERIAL AND METHODS}

This study used 20 rats (Rattus novergicus) aged 3 to 4 months weighing about 20 grams obtained from the Veterinaria Farma Center Surabaya. The study was carried out with the approval of the Study Ethics commission No. 247/HRECC.FORM/IX/2018. Heat exposure was performed in a $50 \times 30 \times 40 \mathrm{~cm}$ chamber with heating lamp and thermostat to keep the temperature at a steady $40^{\circ} \mathrm{C}$ as earlier study (Rohmah et al., 2018).

The watermelon rind extraction in ethanol was carried out at the Pharmacology Laboratory,
Division of Basic Veterinary Medicine, Faculty of Veterinary Medicine, Universitas Airlangga.

\section{Treatment of rats}

Twenty rats were divided randomly into five treatment groups equally. The control group (T0) rats were not exposed to heat nor given the watermelon rind ethanolic extract. The T1, T2, $\mathrm{T} 3$, and T4 groups were exposed to heat for an hour daily and administered orally through a stomach tube with placebo (1\% Na CMC), 100, 200 , and $400 \mathrm{mg} / \mathrm{kg} \mathrm{BW}$ of watermelon rind ethanolic extract dissolved in $1 \% \mathrm{Na} \mathrm{CMC}$. Rats were treated for 52 days, and sacrificed the next day. Testicles were collected for the preparation of hematoxylin-eosin stained histological slides.

\section{Measurement of variables}

Measurement of the number of Leydig, Sertoli, and spermatogenic cells was performed on a 400x magnification light microscope (Nikon E200) equipped with Optilab Viewer Software Version 2.2. The number of Leydig cells was counted randomly on inter seminiferous tubules space. Meanwhile, the number of Sertoli cells and spermatogenic cells were counted in seminiferous tubules. The observations were conducted randomly with five replicates for the averaged of those variables' values.

\section{Data analysis}

Data on the number of Leydig cells, Sertoli cells, and white rat spermatogenic cells were then analyzed statistically using the Analysis of Variance (ANOVA) test and if there were significant differences $(p<0.05)$ followed by multiple distance tests (Duncan) using Statistics Product and Service Solution (SPSS) version 21.

\section{RESULTS}

There were no significant difference ( $\mathrm{p}$ $>0.05$ ) on the average number of Leydig cells in rats among groups. However, the average number of Sertoli cells and spermatogenic cells of rats exposed to heat (T1) was lower than those of the normal rats (T0 group). Administration of watermelon rind extract at the dose of $100 \mathrm{mg} / \mathrm{kg}$ BW (T2 group) resulted in a non significantly different $(p>0.05)$ average number of Sertoli 
cells and spermatogenic cells to the T1 group. Meanwhile, the dose of watermelon rind extract starting from $200 \mathrm{mg} / \mathrm{kg} \mathrm{BW}$ (T3 group) increased $(p<0.05)$ the average number of Sertoli cells and spermatogenic cells than those of the T1 and T2 group. The dose of $400 \mathrm{mg} / \mathrm{kg}$ BW (T4) resulted in a higher average number of Sertoli and spermatogenic cells than those of the T3 group but not significantly different $(p>0.05)$ to those of the normal rats (Table 1).

Table 1 The number of Leydig cells, Sertoli cells, and spermatogenic cells of rats exposed to heat and administered with ethanolic watermelon rind extract

\begin{tabular}{cccc}
\hline & Leydig cells & Sertoli cells & spermatogenic cells \\
\hline T0 & $12,50 \pm 5,07^{\mathrm{a}}$ & $10.00 \pm 0,82^{\mathrm{bc}}$ & $73,00 \pm 5,35^{\mathrm{c}}$ \\
T1 & $8,75 \pm 1,89^{\mathrm{a}}$ & $6,50 \pm 0,58^{\mathrm{a}}$ & $51,00 \pm 5,35^{\mathrm{a}}$ \\
T2 & $7,75 \pm 1,50^{\mathrm{a}}$ & $7,25 \pm 0,50^{\mathrm{a}}$ & $54,25 \pm 3,86^{\mathrm{a}}$ \\
T3 & $14,00 \pm 5,60^{\mathrm{a}}$ & $9,25 \pm 0,50^{\mathrm{b}}$ & $65,50 \pm 3,42^{\mathrm{b}}$ \\
T4 & $13,75 \pm 1,70^{\mathrm{a}}$ & $10,50 \pm 0,58^{\mathrm{c}}$ & $75,00 \pm 1,41^{\mathrm{c}}$ \\
\hline
\end{tabular}

Different superscripts in the same column were significantly different $(\mathrm{p}<0.05)$; $\mathrm{T} 0$ : control group rats, received placebo; T1-T4: rats were exposed to heat for an hour daily for 52 days; T2, T3, and T4: rats were administered 100,200 , and $400 \mathrm{mg} / \mathrm{kg} \mathrm{BW}$ of watermelon rind ethanolic extract orally for 52 days; heat exposure was performed in a heating chamber at $40{ }^{\circ} \mathrm{C}$

\section{DISCUSSION}

Testis is a temperature-sensitive organ that needs to maintain a temperature of $2-7^{\circ} \mathrm{C}$ below core body temperature to ensure the production of normal spermatozoa. Failure to maintain the testicular temperature in mammals impairs spermatogenesis and leads to low spermatozoa counts, poor spermatozoa motility, and abnormal spermatozoa morphology in the ejaculate (Aldahhan and Stanton, 2021).

Exposure to heat only (T1), or its combination with different watermelon rind extract doses (T2-T4), did not affect Leydig cells' number. In the testicle, Leydig cells are not susceptible to heat stress. The cells that are susceptible to heat stress are spermatocytes and spermatids (Hansen, 2009). The effect of heat stress varies on each cell. The Leydig cells receive the effects of heat stress indirectly (Setchel, 1998). This finding was consistent with previous reports that Scrotal hyperthermia $\left(43^{\circ} \mathrm{C}\right.$ for 30 min once daily for six consecutive days) induces Leydig cell damage (Kanter et al., 2009). Meanwhile, the other study reported that testicular exposure to $43^{\circ} \mathrm{C}$ for $30 \mathrm{~min}$ leads to Leydig cell hyperplasia and a reduction in testosterone biosynthesis in adult rat testes ( $\mathrm{Li}$ et $a l .$, 2015). The Leydig cell response to heat stress likely occurs after seminiferous tubule damage (Aldahhan and Stanton, 2021).
The number of Sertoli cells and spermatogenic cells of rats exposed to heat (T1) was lower than those of the normal rats (T0 group). Heat stress is a condition where there is an increase in environmental temperature to affect the body directly. Heat stress increased animal's body temperature above $38{ }^{\circ} \mathrm{C}$ (Bunglavan and Chaturvedi, 2013). In the T1 group, rats were exposed to heat without watermelon rind ethanolic extract administration. The watermelon rind contains antioxidants (Erhirhie and Ekene, 2013; Fila et al., 2013). The lowest number of Sertoli cells and spermatogenic cells of rats in the $\mathrm{T} 1$ group was due to the absence of exogenous antioxidants to protect the Sertoli cells from heat stress-free radicals. In the process of spermatogenesis, Sertoli cells function to nourish spermatogonia cells to develop into primary spermatocytes (Wang et al., 2019). Heat stress exposure to the number of Sertoli cells will cause oxidative stress, a condition where free radicals exceed the body's number of antioxidants (Umar et al., 2015). The low amount of antioxidants in the body cannot protect Sertoli cells from heat stress in the form of free radicals. Oxidative stress will cause a decrease in the synthesis of androgen binding protein $(\mathrm{ABP})$. This protein functions to bind testosterone to the process of spermatozoa cell maturation. The decline in the ABP synthesis process causing this protein is to fail to 
bind testosterone, interfering with spermatogenesis. In addition to decreasing protein synthesis, oxidative stress also causes cell membrane damage. Oxidative stress damages cell membranes by deactivating cell membrane bonds with receptors or enzymes to interfere with the normal function of Sertoli cells (Murray et al., 2003). The disruption of the Sertoli cell's normal function can affect the spermatogenesis process. Spermatogenesis depends on the normal function of Sertoli cells (Min Chen et al., 2008). Sertoli cell damage can be seen in the positive controls treatment that has the lowest number of values. However, no clear evidence has yet emerged to confirm whether Sertoli cells are directly affected by testicular heating or germ cell damage (Aldahhan and Stanton, 2021).

Treatment using watermelon rind extract at the dose of $100 \mathrm{mg} / \mathrm{kg} \mathrm{BW}$ (T2 group) resulted in a non-significant difference $(p>0.05)$ average number of Sertoli cells and spermatogenic cells to the T1 group. Meanwhile, the dose of 200 $\mathrm{mg} / \mathrm{kg}$ BW (T3 group) increased ( $\mathrm{p}<0.05)$ the average number of Sertoli cells and spermatogenic cells than those of the T1 and T2 group. The watermelon rind ethanolic extract administration as an exogenous antioxidant was proved to be able to maintain the number of Sertoli cells. The Lycopene contained in watermelon rind ethanolic extract protects heat stress by reducing single oxygen and free radical deactivators (Sayuti and Yenrina, 2015).

The cells that are susceptible to heat stress are spermatocytes (Hansen, 2009). In the process of spermatogenesis, the mitotic phase, such as spermatocyte cells, is more susceptible to high temperatures (Shiraishi et al., 2012). Heat stress exposure to spermatogenic cells will result in the same oxidative stress occurring in Sertoli cells. Oxidative stress causes damage to the spermatogenic cell membrane. Damage to the spermatogenic cell membrane caused by the number of antioxidants in the body cannot protect and maintain the bond between cell membranes. The spermatogenic cell structure is rich in polyunsaturated fatty acids. This structure makes spermatogenic cells very susceptible to oxidative stress damage. In normal situations, the mechanism of antioxidants present in reproductive tissue tends to reduce oxidative stress and protect spermatogenic cells from oxidative damage (Sikka, 2001). Oxidative stress in spermatogenic cells will decrease enzyme bonds in spermatogenic cells so that it damages cell membranes, damage to cell membranes will interfere with physiology, and spermatozoa motility to interfere with fertilization (Rivlin et al., 2004).

The dose of $400 \mathrm{mg} / \mathrm{kg} \mathrm{BW}$ (T4) resulted in a higher average number of Sertoli cells and spermatogenic cells than those of the $\mathrm{T} 3$ group and not significantly different $(\mathrm{p}>0.05)$ to those of normal rats (Table 1). The testis is a temperature-sensitive organ that needs to be maintained $2-7^{\circ} \mathrm{C}$ below core body temperature to ensure the production of normal spermatozoa. Failure to maintain the testicular temperature in mammals impairs spermatogenesis and leads to low spermatozoa counts, poor spermatozoa motility, and abnormal spermatozoa morphology in the ejaculate. Therefore, there was a need for further studies to explore the role of watermelon rind ethanolic extract on spermatozoa viability, motility, and abnormality, also the levels of testosterone of rats exposed to heat stress.

\section{CONCLUSION}

The administration of watermelon rind ethanolic extract maintained the number of Sertoli and spermatogenic cells of rats exposed to heat but did not affect Leydig cells' number.

\section{REFERENCES}

Aldahhan RA, Stanton PG. 2021. Heat stress response of somatic cells in the testis. Mol Cell Endocrinol. DOI: 10.1016/j.mce.2021.111216.

Asadi N, Bahmani M, Kheradmand A, RafieianKopaei M. 2017 The Impact of Oxidative Stress on Testicular Function and the Role of Antioxidants in Improving it: A Review. J Clin Diagn Res. 11: IE01-IE05.

Bunglavan SJ, Chaturvedi VB. 2013. Heat Stress: Impact on Animal Production and Nutritional Strategies for Mitigation of Heat Stress in Dairy Cattle. Livestock Line. March 2013. 46-9. 
Durairajanayagam D, Agarwal A, Ong C, Prashast P. 2014. Lycopene and male infertility. Asian J Androl. 16: 420-5.

Erhirhie EO, Ekene NE. 2013. Medical Values on Citrullus lanatus Watermelon: Pharmacological Review. Int J Res Pharm Biomed Sci. 4: 1305-12.

Fila WA, Itam EH, Johnson JT, Odey MO, Effiong EE, Dasofunjo K, Ambo EE. 2013. Comparative proximate Compositions of Citrullus Lanatus, Squash Cucurbita Pepo`l and Rambutan Nephelium Lappaceum. Int J Sci Technol. 2: 81-8.

Hansen PJ. 2009. Effects of heat stress on mammalian reproduction. Philos Trans R Soc Lond B Biol Sci. 364: 3341-50.

Kanter M, Aktas C. 2009. Effects of scrotal hyperthermia on Leydig cells in long-term: a histological, immunohistochemical and ultrastructural study in rats. J Mol Histol. 40: 123-30.

Li Z, Tian J, Cui G, Wang M, Yu D. 2015. Effects of local testicular heat treatment on Leydig cell hyperplasia and testosterone biosynthesis in rat testes. Reprod Fertil Dev. 28 DOI: $10.1071 /$ RD14370.

Murray J, Taylor SW, Zhang B, Ghosh SS, Capaldi RA. 2019 SW, Zhang B, Ghosh SS, Capaldi RA. 2003. Oxidative damage to mitochondrial complex I due to peroxynitrite: identification of reactive tyrosines by mass spectrometry. J Biol Chem. 278: 37223-30.

Reynertson KA. 2007. Phytochemical Analysis of Bioactive Constituents from Edible Myrtaceae Fruit, The City University of New York. New York.
Rivlin J, Mendel J, Rubinstein S, Etkovitz N, Breitbart H. 20014. Role of hydrogen peroxide in sperm capacitation and acrosome reaction. Biol Reprod. 70: 518-22.

Rohmah L, Triana IN, Sunarso A, Susilowati S, Hidajati N, Kurnijasanti R. 2018. Pengaruh pemberian ekstrak kulit semangka (Citrullus lanatus) terhadap motilitas dan viabilitas spermatozoa tikus (Rattus norvegicus) dengan paparan suhu panas. Ovozoa 7: 1316.

Sayuti K, Yenrina R. 2015. Antioksidan Alami dan Sintetik. Andalas University Press. Padang.

Shiraishi K, Matsuyama H, Takihara H. 2012. Pathophysiology of varicocele in male infertility in the era of assisted reproductive technology. Int J Urol. 19: 538-50.

Sikka SC. 2001. Relative impact of oxidative stress on male reproductive function. Curr Med Chem. 8: 851-62.

Umar SH, Queljoe ED, Tendean L. 2015. Pengaruh pemberian ekstrak kulit buah Manggis (Garnicinia mangostana L.) terhadap kualitas spermatozoa Wistar jantan (Rattus norvegicus) yang diberi paparan suhu panas. J e-Biomedik 3: 670-5.

Wang Z, Xu X, Li JL, Palmer C, Maric D, Dean J. 2019. Sertoli cell-only phenotype and scRNA-seq define PRAMEF12 as a factor essential for spermatogenesis in mice. Nat Commun. 10: 5196. DOI: 10.1038/s41467019-13193-3.

Werdhasari A. 2014 . Peran Antioksidan Bagi Kesehatan. Jurnal Biotek Medisiana Indonesia 3: 59-68. 